\title{
Population dynamics and spatial distribution of the Calosoma granulatum Perty., 1830 (Coleoptera: Carabidae) in soybean/corn crop
}

\author{
Ivan Carlos Fernandes Martins ${ }^{1 *}$, Francisco Jorge Cividanes ${ }^{2}$, José Carlos Barbosa ${ }^{2}$, Joaquim Alves de Lima \\ Junior ${ }^{1}$, André Luiz Pereira da Silva ${ }^{2}$, Lourival Dias Campos ${ }^{1}$, Gianni Queiroz Haddad ${ }^{2}$, Anderson Gonçalves \\ da Silva ${ }^{3}$
}

\author{
${ }^{1}$ Universidade Federal Rural da Amazônia / UFRA, Capanema Campus, PA, Brazil \\ ${ }^{2}$ Universidade Estadual Paulista / UNESP, Faculty of Agrarian and Veterinary Sciences / FCAV, Jaboticabal, SP, Brazil \\ ${ }^{3}$ Universidade Federal Rural da Amazônia / UFRA, Campus Paragominas, PA, Brazil
}

*Corresponding author: ivan.martins@ufra.edu.br

\begin{abstract}
The (Calosoma granulatum Perty., 1830) (Coleoptera: Carabidae) is an important predator of agricultural pests. The knowledge about the spatial and temporal behavior and influence of the environmental structure may be fundamental for the application of conservative biological control. This study evaluated whether phenology of cultivated plants and meteorological factors influencing the occurrence and spatial distribution of the predaceous beetle (Calosoma granulatum) in soybean/corn crop. Three hypotheses were tested: $\mathrm{H} 1$ : that this predaceous beetle occurs naturally in aggregated spatial patterns; $\mathrm{H} 2$ : its presence/absence in agricultural fields is influenced by meteorolical factors; and H3: the presence of the beetle bank in crop fields affects the carabid spatial distribution patterns. To test these hypotheses, we measured annual population fluctuations to examine the influence of meteorological factors, and to determinate the spatial distribution using dispersion indices and probabilistic models based on the Calosoma granulatum frequency distribution in one hectare of soybean/corn crop using multiple regression analysis (stepwise). The results showed that population peaks of the beetle in soybean crop were coincident with their reproductive period regardless of meteorological factors. The analyses of the spatial distributions showed that Calosoma granulatum has a clustered distribution, and the highest numbers were observed in soybean crop. These results support the hypothesis that the beetles have an aggregated pattern. However, the hypotheses that the occurrence and distribution of this predator is directly influenced by environmental distribution factors and by the presence of herbaceous refuge is not supported.
\end{abstract}

Keywords: Carabid beetles, dispersion indexes, Glycine max, linear interpolation, natural pest control, predator, Zea mays.

Introduction

There is a great diversity and abundance of arthropods that can be found in soybean and corn fields (Cividanes and Yamamoto, 2002; Adams et al., 2017). Nevertheless, the vast majority of studies on arthropods associated with these crops have related to phytophagous insects, probably because of the injury that these organisms cause to crops (Kogan and Turnipssed, 1987). These authors also reported that the natural biological control of soybean crop has been effective, mainly due to the action of arthropod predators. Therefore, ecological studies on those organisms are also required.

The main arthropods predators associated with soil in soybean and corn crops are spiders, rove beetles, ground beetles, earwigs and ants (Bechinski and Pedigo, 1981; Cividanes, 2002; Cividanes et al., 2009). The ground beetles are among the most abundant predators (Witmer et al., 2003). The ground beetles play multiple roles in the ecosystem. They, are reported as predators of agricultural pests (Kromp, 1999), seed predators (Honek et al., 2006) and environmental quality indicators (Pearce and Venier, 2006).
The implementation of refuge areas (beetle banks) in agricultural fields may benefit conservative biological control. Collins et al. (2003) verified that beetle bank can benefit the occurrence of polyphagous predators in agricultural fields. Thomas et al. (1992) reported that carabid species preferably occurs at the boundary (boundary species) or crops (open-field species). The use of refuge islands (beetle banks) within the cultures can increase the effectiveness of boundary species in biological control. Martins et al. (2016) reported that the predator Abaris basistriata Chaudoir, 1873 (Carabidae) used the beetle bank as a refuge island in unfavorable periods in agricultural areas.

The species Calosoma granulatum Perty. 1830, is a predator carabid commonly found in areas cultivated with soybeans (Brondani et al., 2008; Lietti et al., 2008). In laboratory studies, this species consumed a great number of Anticarsia gemmatalis Hübner, 1818 larvae causing high mortality rates (above 90\%) (Pasini 1991, 1995; Cividanes et al., 2014). 
Several biotic and abiotic factors influence the occurrence of carabids in agroecosystems such as temperature, humidity, food supply, presence of competitors and reproductive behavior (Lövei and Sunderland, 1996). These factors can also affect the spatial distribution of carabids and change the aggregation of the species (Dennis et al., 2002).

According to Taylor (1984), most studies on spatial distribution are related to insect pests of agricultural systems. However, knowledge of the spatial distribution of natural enemies seems to be essential for the understanding of natural and applied biological control and development of strategies to be implemented in integrated pest management (Hajek, 2004). The use of tools for the Geostatistics is valuable to investigate the behavior and spatial pattern of insect populations and to support integrated pest management (Sciarretta and Trematerra, 2014).

The structure and environmental conditions may interfere with the occurrence of insects in agricultural areas and beetle Calosoma granulatum presents potential in the biological control of pests. The following research questions were elaborated: How is the spatial and temporal behavior of Calosoma granulatum in an agricultural area? Meteorological factors, phenological stages of cultivated plants and the presence of beetle bank influence this behavior? To answer these questions, we elaborate the following hypotheses, $\mathrm{H} 1$ : The spatial patterns of this predatory beetle occur naturally in aggregate form; $\mathrm{H} 2$ : its presence / absence in agricultural fields is influenced by meteorological factors and phenological stages of cultivated plants; and H3: the presence of the beetle bank in the cultivated fields benefits the occurrence of Calosoma granulatum. Based on the questions and hypotheses the objectives of this study were to analyze the population dynamics and spatial distribution of adult Calosoma granulatum in soybean / corn crops with the presence of a beetle bank.

\section{Results and discussion}

\section{Occurrence of Calosoma granulatum}

Throughout the sample period, there was a total of 366 specimens of C. granulatum, of which 317 (86.61\%) specimens occurred in soybean, indicating mean number of 3.3 equivalent per trap specimens, and only 49 specimens in the area of refuge (Table 1). Plots of the grass Panicum maximum Jacq. and the legume Calopogonium mucunoides Desv. were those with the larger number of specimens, 18 and 15 , respectively, when compared to the plots of the grass Cynodon spp. and the legume Stylosanthes spp. in the beetle bank (Table 1 ). The $C$. granulatum beetle has a preference for occurring in agricultural areas, mainly soybean crop, being considered a dominant species in this environment (Martins et al., 2009; Martins et al., 2012).

\section{Population dynamics}

The population fluctuation of $C$. granulatum demonstrated that the species was present during almost the entire study period, being absent only in five of 27 samples carried out. The highest population peaks of this species occurred in the seasons of soybean during the month of February (Fig. 2). Moreover, it was observed peak population $C$. granulatum in periods of high rainfall, and maximum and minimum temperatures around $30^{\circ} \mathrm{C}$ and $20^{\circ} \mathrm{C}$, respectively. However, the only meteorological factor that showed significant regression coefficient of $10 \%$ was the minimum temperature, which explained only $10.37 \%$ of the observed variation in the occurrence of $C$. granulatum (parameter: $\left.2.44191, F=2.89, R^{2}=0.1037\right)$. The statistical results do show the influence of the meteorological factors analyzed on the occurrence of $C$. granulatum. However, Fig. 2 shows a trend of increasing population in periods of high humidity due to rainfall and high temperatures. Martins et al. (2009) verified that rainfall influenced positively the occurrence of C. granulatum in the soybean crop. Barros et al. (2006) report the peak population of $C$. granulatum in cotton, 55 days after emergence of the crop, period with high temperature and humidity.

The variation in population density with the phenological phases of the soybeans showed that the highest population peaks occurrs during the reproductive period of soybean (Fig. 3). However, the developmental stage of highest occurrence differed in seasons. In 2008/09, population peak occurred in the R3 up to R5 stage (beginning of fruit set to the beginning of grain filling), while in 2009/10 season, the peak occurred in the R1 and R2 stages (beginning of flowering and full flowering) (Fig. 3). Similar results were observed by Pegoraro and Foerster (1988) that verified a highest incidence of $C$. granulatum between R2 and R6 soybean stages. Other carabids of the genus Callida and Lebia (Didonet et al., 2003) and Abaris (Martins et al., 2016) were also observed with highest occurrence in the reproductive stage of soybean.

The population peaks were occurred in the same period of the year (February), when the soybeans did not have the same developmental stage. Also, a low correlation with temperature and rainfall was onserved that may indicate that the occurrence of $C$. granulatum is cyclical and related to other environmental factors. The presence of the prey is one of the factors that may influence the occurrence of $C$. granulatum. Bueno et al. (2012) reported that from December to early April, there is a large occurrence of $C$. granulatum larvae in the soybean crop, and that these are voracious predators of the soybean caterpillar ( $A$. gemmatalis). Didonet et al. (2003) found that the caterpillar A. gemmatalis has population peaks mainly in the reproductive period of soybean, being able to attract and increase in population of this predator in the culture.

The mean population of $C$. granulatum was higher in soybean at 2008/09 season than in 2009/10 (Table 2). The values obtained in the variance/mean (i) were higher than unit in four dates in the $2008 / 09$ season ( $\operatorname{Jan} 28^{\text {th }}$, Feb $11^{\text {th }}$, Feb $25^{\text {th }}$ and Mar $11^{\text {th }}, 2009$ ) and five dates in 2009/10 (Feb $03^{\text {rd }}$, Feb $10^{\text {th }}$, Feb $24^{\text {th }}$, Mar $24^{\text {th }}$ and Apr 21 $1^{\text {st }}, 2010$ ), coinciding with the periods of highest occurrence of $C$. granulatum (Table 2), demonstrating that this predator has a clustered distribution. The values given in Morisita index $\left(\mathrm{I}_{\delta}\right)$ also indicated aggregation of the beetle, in the same period of highest occurrence. Aggregate spatial distribution seems to be the standard for this species. Barros et al. (2006), used Morisita index and found that $C$. granulatum also has aggregate distribution in cotton.

The values obtained for the $k$ parameter of negative binomial distribution, estimated by the method of moments, showed positive values but lower than two in all dates of 
Table 1. Calosoma granulatum specimens sampled in the experimental area. Jaboticabal, SP, Brazil, 2008, 2009 and $2010 .(\%=$ Percent of the total of specimens; Mean number = number of specimens / number of traps).

\begin{tabular}{lccc}
\hline Area sampling & Specimens number & $\%$ & Mean number \\
\hline Arable field & 317 & 86.6 & 3.3 \\
Calopogonium mucunoides & 15 & 4.1 & 2.5 \\
Cynodon spp. & 8 & 2.19 & 1.3 \\
Panicum maximum & 18 & 4.92 & 3.0 \\
Stylosanthes spp. & 8 & 2.19 & 1.3 \\
\hline Total & 366 & 100 & \\
\hline
\end{tabular}

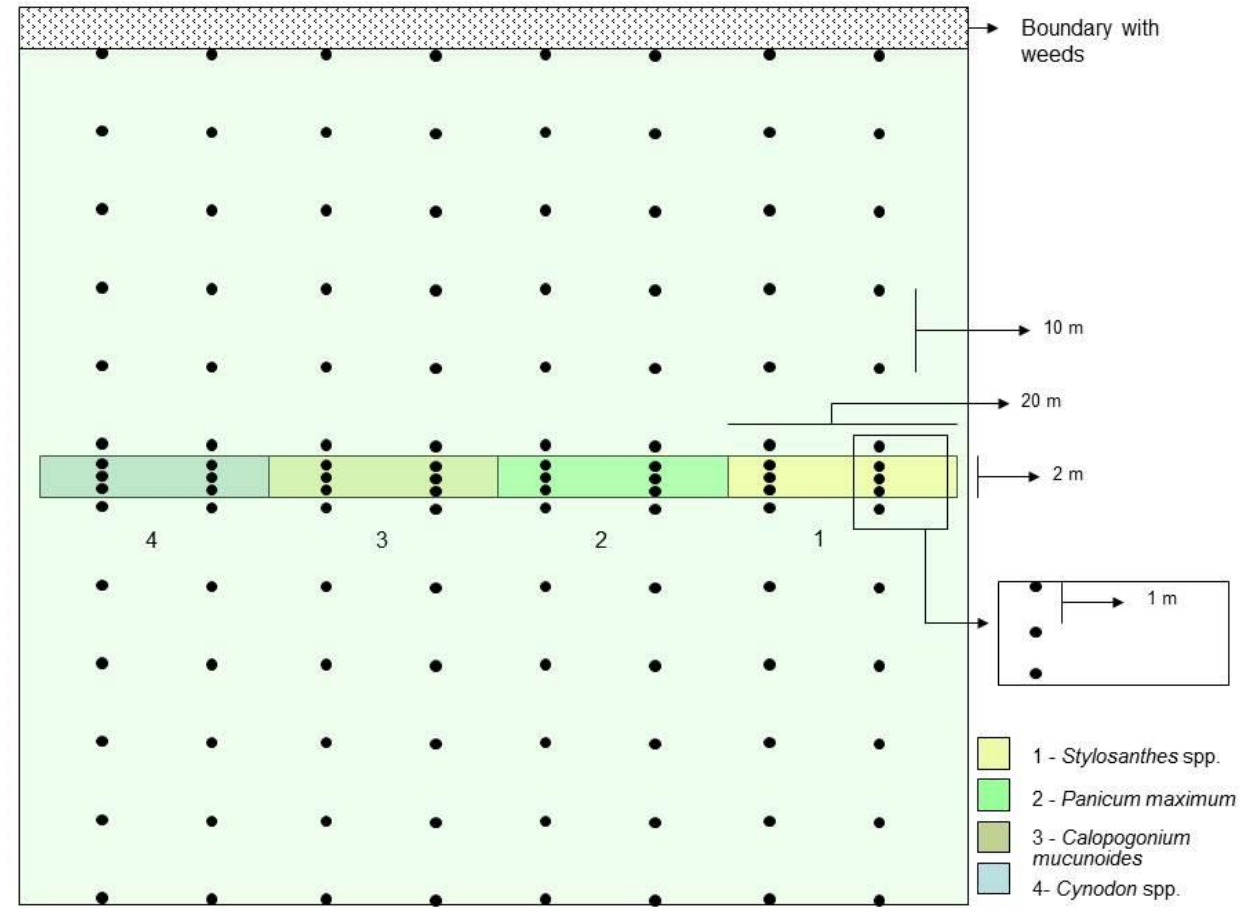

Fig 1. Design of the experimental area showing the position of the beetle bank (central bar). Dots represent location of traps. The central beetle bank was surrounded by a soybean field (season: 2008/09 and 2009/10), a corn field (offseason: 2009), and fallow (offseason: 2010).

Table 2. Means, variances and dispersion indexes for the occurrence of Calosoma. granulatum throughout the sampling period. Jaboticabal, SP - Brazil.

\begin{tabular}{|c|c|c|c|c|c|c|c|c|c|c|c|c|c|c|}
\hline \multirow{2}{*}{ Indexes } & \multicolumn{8}{|c|}{ Soybean crop } & \multicolumn{6}{|c|}{ Corn crop } \\
\hline & 0.0000 & 0.0083 & 0.0417 & 0.2000 & 0.6500 & 0.6750 & 0.1083 & 0.0000 & 0.0333 & 0.0167 & 0.0250 & 0.0500 & 0.0167 & 0.0083 \\
\hline$s^{2}$ & - & 0.0083 & 0.0403 & 0.6151 & 1.1370 & 0.9607 & 0.1646 & - & 0.0325 & 0.0165 & 0.0246 & 0.0479 & 0.0165 & 1.0000 \\
\hline $\mathrm{I}=\mathrm{s}^{2} / \mathrm{m}$ & - & 1.0000 & 0.9664 & 3.0756 & 1.7492 & 1.4233 & 1.5197 & - & 0.9748 & 0.9916 & 0.9832 & 0.9580 & 0.9916 & 0.0000 \\
\hline $\mathrm{I}_{\delta}$ & - & 0.0000 & 0.0000 & 11.7391 & 2.1578 & 1.6296 & 6.1538 & - & 0.0000 & 0.0000 & 0.0000 & 0.0000 & 0.0000 & 119.00 \\
\hline$x^{2} I_{\delta}$ & - & 119.00 & 115.00 & 366.00 & 208.15 & 169.37 & 180.85 & - & 116.00 & 118.00 & 117.00 & 114.00 & 118.00 & - \\
\hline $\mathrm{K}$ mom & - & - & -1.2396 & 0.0964 & 0.8676 & 1.5947 & 0.2084 & - & -1.3222 & -1.9833 & -1.4875 & -1.1900 & -1.9833 & - \\
\hline$C x$ & - & - & -0.0084 & 0.0902 & 0.0097 & 0.0053 & 0.0433 & - & -0.0084 & -0.0084 & -0.0084 & -0.0084 & -0.0084 & \\
\hline Indexes & \multicolumn{2}{|c|}{ Fallow } & \multicolumn{8}{|c|}{ Soybean crop } & \multicolumn{4}{|c|}{ Fallow } \\
\hline $\mathrm{m}$ & 0.0333 & 0.0083 & 0.0417 & 0.0000 & 0.2583 & 0.4583 & 0.2000 & 0.0000 & 0.0333 & 0.0583 & 0.0500 & 0.1083 & \multicolumn{2}{|c|}{0.0000} \\
\hline$s^{2}$ & 0.0325 & 0.0083 & 0.0403 & - & 0.6302 & 0.7377 & 0.2622 & - & 0.0493 & 0.0554 & 0.0647 & 0.0974 & \multicolumn{2}{|c|}{-} \\
\hline $\mathrm{I}=\mathrm{s}^{2} / \mathrm{m}$ & 0.9748 & 1.0000 & 0.9664 & - & 2.4394 & 1.6096 & 1.3109 & - & 1.4790 & 0.9496 & 1.2941 & 0.8992 & \multicolumn{2}{|c|}{-} \\
\hline$I_{\delta}$ & 0.0000 & 0.0000 & 0.0000 & - & 6.7097 & 2.3434 & 2.6087 & - & 20.0000 & 0.0000 & 8.0000 & 0.0000 & \multicolumn{2}{|c|}{-} \\
\hline$x^{2} I_{\delta}$ & 116.00 & 119.00 & 115.00 & - & 290.29 & 191.55 & 156.00 & - & 176.00 & 113.00 & 154.00 & 107.00 & \multicolumn{2}{|c|}{-} \\
\hline $\mathrm{K}$ mom & -1.3222 & - & -1.2396 & - & 0.1795 & 0.7518 & 0.6432 & - & 0.0696 & -1.1569 & 0.1700 & -1.0743 & \multicolumn{2}{|c|}{ - } \\
\hline$C x$ & -0.0084 & - & -0.0084 & - & 0.0480 & 0.0113 & 0.0135 & - & 0.1597 & -0.0084 & 0.0588 & -0.0084 & \multicolumn{2}{|c|}{ - } \\
\hline
\end{tabular}




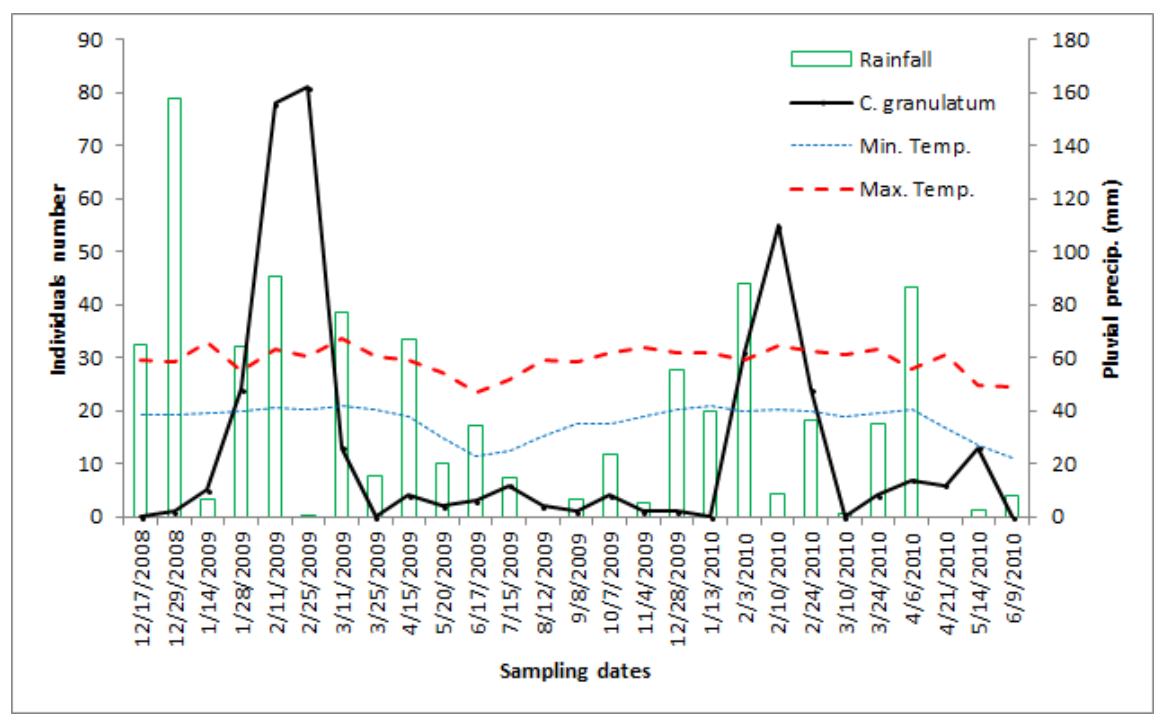

Fig 2. Population fluctuation of Calosoma granulatum, rainfall and maximum and minimum temperature during the entire sampling period, Jaboticabal, SP - Brazil.

Table 3. Results obtained in the chi-square to adjust the Poisson and negative binomial distributions data of adults Calosoma granulatum. Jaboticabal, SP - Brazil.

\begin{tabular}{lllllll}
\hline Dates & \multicolumn{3}{l}{ Poisson } & \multicolumn{3}{c}{ Negative Binominal } \\
\hline & $\mathrm{X}^{2}$ & $\mathrm{df}$ & $\mathrm{p}$ & $\mathrm{X}^{2}$ & $\mathrm{df}$ & $\mathrm{p}$ \\
\hline $28 / 01 / 2009$ & $12.4814^{* *}$ & 1 & 0.0004 & $0.8589^{\text {ns }}$ & 2 & 0.6509 \\
$11 / 02 / 2009$ & $5.9008^{*}$ & 2 & 0.0523 & $2.7435^{\text {ns }}$ & 3 & 0.4329 \\
$25 / 02 / 2009$ & $6.1868^{\text {ns }}$ & 3 & 0.1029 & $4.3003^{\text {ns }}$ & 2 & 0.1165 \\
$03 / 02 / 2010$ & $12.1130^{* *}$ & 1 & 0.0005 & $1.0612^{\text {ns }}$ & 2 & 0.5882 \\
$10 / 02 / 2010$ & $17.2353^{* *}$ & 2 & 0.0002 & $2.7046^{\text {ns }}$ & 2 & 0.2586 \\
$24 / 02 / 2010$ & $1.5601^{\text {ns }}$ & 1 & 0.2116 & IDF & IDF & IDF
\end{tabular}

$\mathrm{x}^{2}=$ Statistics of the chi-square; $\mathrm{df}$ = number of degrees of freedom chi-square; $\mathrm{p}=$ probability level of the chi-square; ${ }^{*}$ Significant at $5 \%$ probability; ${ }^{* *}$ Significant at $1 \%$ probability; ${ }^{\text {Ns }}$ No significant at $5 \%$ probability; IDF = insufficient degree of freedom.

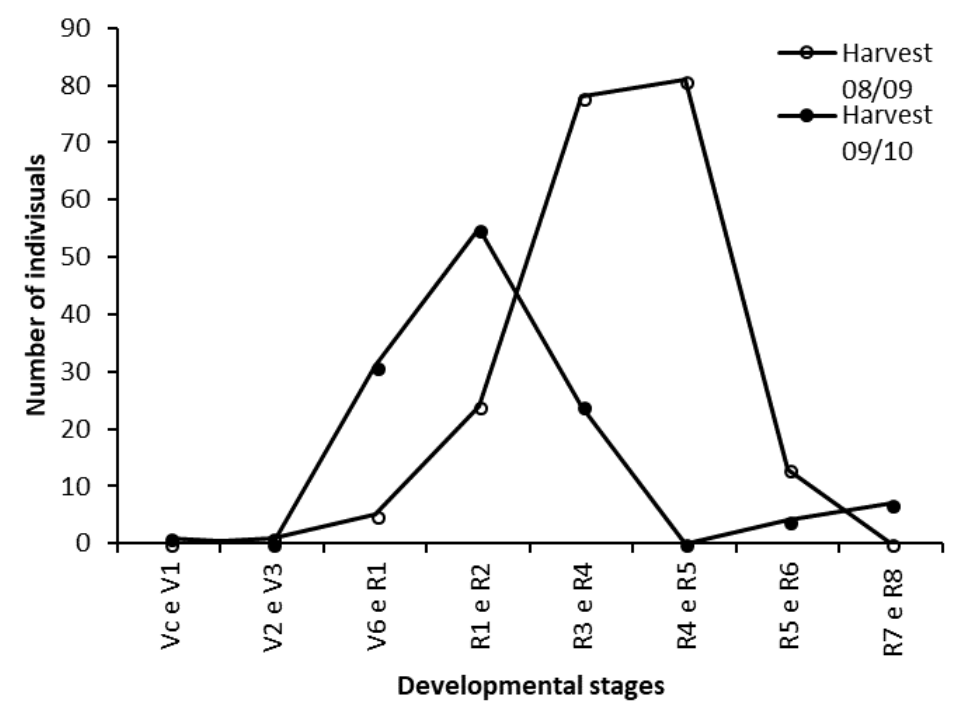

Fig 3. Population fluctuation of Calosoma granulatum in relation to developmental stages of the soybean, Jaboticabal, SP - Brazil. Soybean phenological stages: vegetative $=\mathrm{Vc}-\mathrm{V} 6$; flowering $=\mathrm{R} 1$ and R2; fruiting $=\mathrm{R} 3-\mathrm{R} 6$; maturation $=\mathrm{R} 7$ and $\mathrm{R} 8$. 


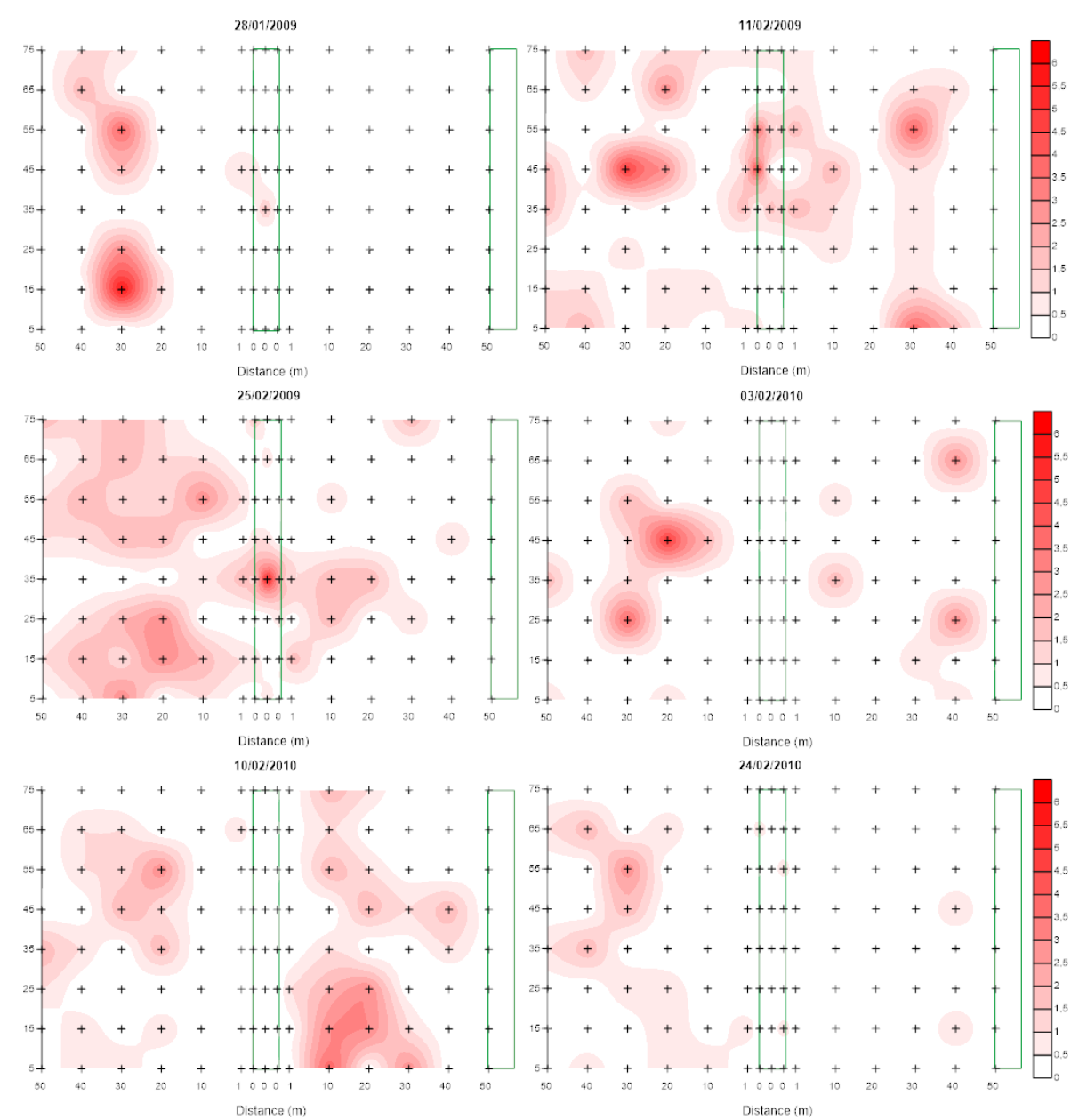

Fig 4. Maps of linear interpolation of Calosoma granulatum adults during the periods, when there was an adjustment to the models of spatial distribution (soybean). The area delimited and zero distance corresponds to the beetle bank. The area delimited on the right, the border of the cultivated area, and the + sign corresponds to the position of the traps in the soil; darkening indicates a higher density of insects. Jaboticabal, SP - Brazil.

highest occurrence of adult C. granulatum, indicating high aggregation of the beetle. This distribution was confirmed by analysis of the coefficient of Green, which in the same dates showed values higher than zero, indicating aggregate distribution of the population (Table 2).

The results obtained in the chi-square for the Morisita index indicated departure from randomness in the dates of highest incidence of $C$. granulatum, but at the other randomness dates was not rejected (Table 2).

Initially, the adjustment of the data was tested to a probabilistic model of the Poisson distribution. However, the model of the Negative Binomial distribution was used because the mean was lower than the variance in the dates of occurrence of $C$. granulatum (Table 2).

In six evaluations, where the degrees of freedom were sufficient for the analysis, the majority of the chi-square values were significant at $1 \%$ or $5 \%$ probability for the adjustment of the Poisson distribution. It was not significant in only two dates, demonstrating that most of the evaluation was not randomly distributed (Table 3 ). Considering the negative binomial distribution, the values were not significant in all evaluations, in which there was sufficient degree of freedom, confirming the clustered distribution of C. granulatum (Table 3).
Samples that were adjusted to the probabilistic models of spatial distribution were used to obtain maps of linear interpolation, which provided the visualization of the distribution of clusters from C. granulatum, determined by dispersion index and adjustment to the negative binomial distribution model (Fig. 4).

The refuge areas may act as areas of aggregation of some carabids species (Collins et al., 2002; Martins et al., 2016). In the present study, this hypothesis was rejected because the majority of aggregation of $C$. granulatum was occurred in the area cultivated with soybeans, demonstrating that this species prefers to concentrate in this habitat (Fig. 4). These results corroborate with those reported by Cividanes and Santos-Cividanes (2008) and Cividanes et al. (2009) that found a preference for $C$. granulatum to occur in areas of annual crops.

Based on the results, it was verified that the occurrence and clustered distribution of $C$. granulatum in areas of soybean is slightly related to meteorological factors (temperature and pluvial rainfall), phenological stages and the presence of refuge area. In future studies, new variables must be included and analyzed separately or in groups, to better clarify the behavior of this predator. 


\section{Materials and methods}

\section{Experimental area}

This study was carried out in a $100 \times 100-\mathrm{m}$ area located on 10 ha of land that belongs to the Faculty of Agricultural and Veterinary Sciences (FCAV), São Paulo State University (UNESP), Jaboticabal Municipality, SP, Brazil (latitude: $21^{\circ} 15^{\prime} 29^{\prime \prime}$ south and longitude: $48^{\circ} 16^{\prime} 54^{\prime \prime \prime}$ west).

Based on the methods described by Collins et al. (2003), a beetle bank $80-\mathrm{m}$-long, 2-m-wide, and 40-cm-high space at the center of this area was implanted as a shelter island (also known as refuge or beetle island) for the natural enemies (Fig. 1). This beetle bank was divided into four 20-m plots cultivated with the following perennial herbaceous plant types: Panicum maximum 'Massai', Cynodon spp. 'Tifton 85', Stylosanthes spp. 'BRS Campo Grande', and Calopogonium mucunoides 'Common' (Fig. 1). To select herbaceous plants to be used in areas of refuge, several characteristics were considered such as rapid growth, resistance to adverse conditions of humidity and temperature, low need for cultivation, durability and reduced potential of becoming weeds (Thomas et al., 1992; MacLeod et al., 2004).

The remaining of the field was cultivated with: i) soybeans during the 2008/09 and 2009/10 season, ii) corn in 2009 offseason, and ii) kept in fallow during 2010 off-season, after soybean harvest. During all experimentation period, no insecticide applications were made, but there were two applications of fungicides and herbicides in each season of soybeans, between the months of January and February. The sowing of soybean in 2008/09 season occurred on December $05^{\text {th }}, 2008$ and harvest on March 27 $7^{\text {th }}, 2009$, while in $2009 / 10$ the sowing and harvest occurred on December $17^{\text {th }}$, 2009 and April 12 $2^{\text {th }}, 2010$, respectively. Corn was sown on April $03^{\text {rd }}, 2009$ and harvest occurred on November $25^{\text {th }}$, 2009.

\section{Sampling insects}

Beetles were collected using pitfall traps made with $500 \mathrm{ml}$ plastic cups ( $80 \mathrm{~mm}$ diameter $\times 140 \mathrm{~mm}$ high) containing a mixture of water $(150 \mathrm{ml})$, formaldehyde $(1 \%)$ and some drops of neutral detergent. Each trap was covered with a 15 $\mathrm{cm}$ diameter hard plastic and installed $3 \mathrm{~cm}$ above the trap. Sampling frequency was every 15 days during the season and once in a month in the off-season. They were kept from December 17th, 2008 to June 09th, 2010, for a total of 27 sampling dates. The traps were installed in the field for a week, and they were subsequently removed and sent to the laboratory for screening, assembly, and specimen labeling. For each block of herbaceous plants, six traps (separated by 1 meter) were installed in two parallel rows, keeping a distance of $10 \mathrm{~m}$ from each other (Fig. 1). In the field, traps were installed using distribution grid, based on the method used by Holland et al. (1999) and Thomas et al. (2002). Concerning the traps located in the surrounding field crops, the first row of them was kept $1 \mathrm{~m}$ apart from the beetle bank area and $10 \mathrm{~m}$ apart from each other all over the remaining area.

\section{Meteorological factor}

To study the influence of meteorological factor on the fluctuations in the population of Carabid beetles, the total number of specimens of $C$. granulatum occurring in all the traps during the sampling period was considered. This was accomplished by using multiple regression analysis with variable selection using the "stepwise" procedure of SAS (Draper and Smith, 1981) and considering 10\% of significance as the threshold for the inclusion or exclusion of independent variables (temperature and rain). Meteorological factors considered included maximum and minimum temperatures $\left({ }^{\circ} \mathrm{C}\right)$ and rainfall $(\mathrm{mm})$. The meteorological data used were gathered from the area of Agrometeorology, FCAV/UNESP in Jaboticabal. In order to run the analysis, mean week temperatures and the sum of week rainfall prior (one week before) to the sampling day were used.

\section{Phenological stages}

Phenological stages of the cultivated plants were determined on the day of sampling, and the dominant phenological phase around each trap was visually observed. The dominant phenological phases were determined using the percentage of individuals verified on the basis of the presence or absence of plants with a determined phenology, according to the methodology used by Bencke and Morellato (2002). This method is a quantitative analysis at the population level and determines the percentage of individuals in the population of plants that expresses particular phenological event. The phenological stages of the soybeans were assessed in accordance with the description of Fehr et al. (1971) and Câmara (1998).

\section{Spatial distribution}

To determine the spatial distribution of adult $C$. granulatum, the mean $(\widehat{\mathrm{m}})$ and variance $\left(\mathrm{s}^{2}\right)$ were calculated and used for the estimation of the dispersion indexes: variance/mean (I), Morisita index $\left(I_{\delta}\right)$, coefficient of Green $(C x)$ and $k$ estimated by the method of moments. The frequency distribution data were tested to determine whether the data fit Poisson and negative binomial distributions.

The relationship of variances and means were calculated as a way to measure the deviation from a random arrangement of conditions. Values equal to unity indicates random spatial distribution, in which values lower than unity indicate a uniform distribution; and values greater than unity, aggregate distribution (Rabinovich, 1980). This index was calculated by the following formula:

$\mathrm{I}=\frac{\mathrm{s}^{2}}{\widehat{\mathrm{m}}}=\frac{\sum_{\mathrm{i}=1}^{\mathrm{n}}\left(\mathrm{x}_{\mathrm{i}}-\widehat{\mathrm{m}}\right)^{2}}{\widehat{\mathrm{m}}(\mathrm{n}-1)}$

Where: $\mathrm{s}^{2}=$ sample variance; $\widehat{\mathrm{m}}=$ sample mean; $\mathrm{x}_{\mathrm{i}}=$ number of $C$. granulatum found in the sampling unit; $n=$ number of sample units.

The Morisita index $\left(I_{\delta}\right)$ indicates the random distribution when it is equal to 1 , contagious distribution when it is greater than 1, and regular when it is lower than 1 , Morisita (1962) developed the following formula:

$$
\mathrm{I}_{\delta}=\mathrm{n} \frac{\sum\left[\mathrm{x}_{\mathrm{i}}\left(\mathrm{x}_{\mathrm{i}}-1\right)\right]}{\sum \mathrm{x}_{\mathrm{i}}\left(\sum \mathrm{x}_{\mathrm{i}}-1\right)}=\frac{\sum_{\mathrm{i}=1}^{\mathrm{n}} \mathrm{x}_{\mathrm{i}}^{2}-\sum \mathrm{x}_{\mathrm{i}}}{\left(\sum_{\mathrm{i}=1}^{\mathrm{n}} \mathrm{x}_{\mathrm{i}}\right)^{2}-\sum \mathrm{x}_{\mathrm{i}}}
$$

Where: $\mathrm{n}=$ number of sample units; $\mathrm{x}_{\mathrm{i}}=$ number of $C$. granulatum found in the sampling units; $\Sigma x_{i}=$ number of individuals found in the sample units.

Test for randomness is given by: 


$$
\chi_{\delta}^{2}=\mathrm{I}_{\delta}\left(\sum_{\mathrm{i}=1}^{\mathrm{n}} \mathrm{x}_{\mathrm{i}}-1\right)+\mathrm{n}-\sum_{\mathrm{i}=1}^{\mathrm{n}} \mathrm{x}_{\mathrm{i}} \sim \mathrm{x}^{2}{ }_{(\mathrm{n}-1)}
$$

If $\chi_{\delta}^{2} \geq X_{(n-1 \text { g.l.;0,05) }}^{2}$, the hypothesis of randomness is rejected.

The coefficient of Green $(C x)$ values range from negative to uniform distributions. Values equal to 0 denote random distributions, and values equal to 1 indicate maximum contagion (Green, 1966). The index is based on variance/mean distributions

$$
C x=\left[\left(\frac{s^{2}}{\widehat{m}}\right)-1\right] /\left[\sum_{i=1}^{n} x_{i}-1\right]
$$

Probabilistic models were adjusted to study the distribution frequency of the species: Data from each sample were tested to check if the Poisson distribution is adjusted. The hypothesis is when the data adjusted into this model is that all specimens are likely equal to occupy a certain space, and the presence of an individual does not affect the presence of another, and the variance equals the mean $\left(\sigma^{2}=\mu\right)$ (Barbosa and Perecin, 1982). In cases where the variance is greater than the mean $\left(\sigma^{2}>\mu\right)$ aggregation of individuals occurs, i.e., the presence of an individual increases the chance that another occurs in the same unit. Then data adjusts to the negative binomial distribution (Barbosa and Perecin, 1982). In that case, first it is necessary to estimate the $k$ exponent of the negative binomial distribution: through the method of moments and given by the following formula:

$$
k=\frac{\widehat{m}^{2}}{s^{2}-\widehat{m}}
$$

When this variable assumes negative values, a uniform distribution is assumed; when the values are low and positive $(k<2)$, a highly aggregated value is present; values ranging from 2-8 indicate moderate aggregation and values greater than $8(k>8)$ account for random aggregation (Elliott, 1979).

For both Poisson and negative binomial distributions, the models are properly adjusted when the frequency data observed and expected values are close. The closeness of these data is compared by the chi-square $(\chi 2)$, given by:

$\chi^{2}=\sum_{i=1}^{N_{c}} \frac{\left(F O_{i}-F E_{i}\right)^{2}}{F E_{i}}$

Where: $\mathrm{FO}_{\mathrm{i}}=$ observed frequency in the ith class; $\mathrm{FE}_{\mathrm{i}}=$ expected frequency in the ith class; $\mathrm{nc}=$ number of classes of the frequency distribution.

The number of degrees of freedom in the $\chi^{2}$ test is given by:

$$
\text { D. F. }=\mathrm{N}_{\mathrm{C}}-\mathrm{N}_{\mathrm{P}}-1
$$

Where: $N_{C}=$ number of classes of the frequency distribution; $N_{P}=$ number of estimated parameters in the sample.

The test criterion used was to reject the adjustment of the distribution studied at $5 \%$ probability if:

$\chi^{2} \geq \chi^{2}{ }_{\left(N_{C}-N_{P}-1 ; \alpha=0,05\right)}$

To illustrate and verify the aggregational and spatial distribution, maps of linear interpolation were used. We demonstrated the values of the observed frequency at the sampling points and the interpolation between points. Surfer 11.0 (Golden Software Inc, 2012) for Windows software was used to obtain the maps of interpolation.

\section{Conclusion}

The Calosoma granulatum presents an aggregated pattern of spatial distribution with preference in occurrence in soybean, especially during the reproductive period of the crop. The temperature, rainfall factors and beetle bank have low influence on the occurrence of this predatory beetle.

\section{Acknowledgments}

To employees Alex Antonio Ribeiro and José de Souza Altamiro of the Departamento de Fitossanidade of the Universidade Estadual Paulista (UNESP) in Jaboticabal, SP, for helping in the development of this study. To Fundação de Amparo à Pesquisa do Estado de São Paulo (FAPESP) for providing the Ph.D. scholarship granted to the first author.

\section{References}

Adams PR, Orr DB, Arellano C, Cardoza YJ (2017) Soil and foliar arthropod abundance and diversity in five cropping systems in the coastal plains of North Carolina. Environ Entomol. 46: 771-783.

Barbosa JC, Perecin D (1982) Modelos probabilísticos para distribuições de lagartas de Spodoptera frugiperda (J. E. SMITH, 1797), na cultura do milho. Cient. 10: 181-91.

Barros R, Degrande PE, Ribeiro JF, Rodrigues ALL, Nogueira RF, Fernandes MG (2006) Flutuação populacional de insetos predadores associados a pragas do algodoeiro. Arq Inst Biol. 73: 57-64.

Bechinski EJ, Pedigo LP (1981) Ecology of predaceous arthropods in lowa soybean agroecosystems. Environ Entomol. 10: 771-778.

Bencke CSC, Morellato LPC (2002) Comparação de dois métodos de avaliação da fenologia de plantas, sua interpretação e representação. Rev Bras Bot. 25: 269-275.

Brondani D, Guedes JVC, Farias JR, Bigolin M, Karlec F, Lopes SJ (2008) Ocorrência de insetos na parte aérea da soja em função do manejo de plantas daninhas em cultivar convencional e geneticamente modificada resistente a glyphosate. Cienc Rural. 38: 2132-2137.

Bueno AF, Sosa-Gómez DR, Corrêa-Ferreira BS, Moscardi F, Bueno RCOF (2012) Inimigos naturais das pragas da soja. In: Hoffmann-Campo CB, Corrêa-Ferreira BS, Moscardi F, (eds.) Soja: Manejo integrado de pragas e outros artrópodes, Brasilia: Embrapa, p. 305-344.

Câmara GMS (1998) Fenologia da soja. In: Câmara GMS (ed) Soja: tecnologia da produção, Rio de janeiro: Editora Publique, p.26-39.

Cividanes FJ (2002) Efeito do sistema de plantio e consorciação soja-milho sobre artrópodes capturados no solo. Pesqui Agropecu Bras. 37: 15-23.

Cividanes FJ, Barbosa JC, Martins ICF; Pattaro F, Nunes MA, Santos RS (2009) Diversidade e distribuição espacial de artrópodes associados ao solo em agroecossistemas. Bragantia. 68: 991-1002.

Cividanes FJ, Ide S, Ribeiro AA, Santos-Cividanes TM (2014) Potencial predatório de Carabidae e Staphylinidae (Coleoptera) sobre a lagarta-da-soja. Pesq Agropec Bras. 49: 652-655.

Cividanes FJ, Santos-Cividanes TM. 2008. Distribuição de Carabidae e Staphylinidae em agroecossistemas. Pesqui Agropecu Bras. 43: 157-162. 
Cividanes FJ, Yamamoto FT (2002) Pragas e inimigos naturais na soja e no milho cultivados em sistema diversificado. Sci Agric. 59: 683-687.

Collins KL, Boatman ND; Wilcox A, Holland JM (2003) A 5year comparison of overwintering polyphagous predator densities within a beetle bank and two conventional hedgebanks. Ann Appl Biol. 143: 63-71.

Collins KL, Boatman ND, Wilcox A, Holland JM, Chaney K (2002) Influence of beetle banks on cereal aphid predation in winter wheat. Agr Ecosyst Environ. 93: 337-350.

Dennis P, Aspinall RJ, Gordon IJ (2002) Spatial distribution of upland beetles in relation to landform, vegetation and grazing management. Basic Appl Ecol. 3: 183-193.

Didonet J, Sarmento RA, Aguiar RWS, Santos GR, Erasmo EAL (2003) Abundância de pragas e inimigos naturais em soja na região de Gurupi, Brasil. Rev Man Integ Plag Agroecol. 69: 50-57.

Draper NR, Smith H (1981) Applied regression analysis, 2nd ed. New York: John Wiley.

Elliott JM (1979) Some methods for the statistical analysis of sample benthic invertebrates. Freshwater Biol. Assoc. Ambleside, UK.

Fehr WR, Caviness SCE, Burmwood DT, Pennington JS (1971) Stage of development descriptions for soybean, Glycine max (L.) Merrill. Crop Sci. 11: 929-931.

Golden-Software Inc. (2012) Surfer 11.0 (Surface Mapping System). Golden, USA. www.goldensoftware.com.

Green RH (1966) Measurement of non-randomness in spatial distributions. Res Pop Ecol. 8: 1-7.

Hajek AE (2004) Natural Enemies: An Introduction to Biological Control. Cambridge: Cambridge University Press, 378p.

Honek A, Saska P, Martinkova Z (2006) Seasonal variation in seed predation by adult carabid beetles. Entomol Exp Appl. 118: 157-162.

Holland JM, Perry JN, Winder L (1999) The within-field spatial and temporal distribution of arthropods in winter wheat. Entomol Res. 89: 499-513.

Kogan M, Turnipseed SG (1987) Ecology and management of soybean arthropods. Annu Rev Entomol. 32: 507-538.

Kromp B (1999) Carabid beetles in sustainable agriculture: a review on pest control efficacy, cultivation impacts and enhancement. Agr Ecosyst Environ. 74: 187-228.

Lietti M, Gamundi JC, Montero G, Molinari A, Bulacio V 2008. Efecto de dos sistemas de labranza sobre la abundancia de artrópodos que habitan en el suelo. Ecol Austral. 18: 7187.

Lövei GL, Sunderland KD (1996) Ecology and behavior of ground beetles (Coleoptera: Carabidae). Annu Rev Entomol. 41: 231-256.

MacLeod A, Wratten SD, Sotherton NW, Thomas MB (2004) 'Beetle banks' as refuges for beneficial arthropods in farmland: long-term changes in predator communities and habitat. Agr Forest Entomol. 6: 147-154.
Morisita M (1962) Id-index, a measure of dispersion of individuals. Res Popul Ecol. 4: 1-7.

Martins ICF, Cividanes FJ, Barbosa JC, Araujo ES, Haddad GQ (2009) Análise de fauna e flutuação populacional de Carabidae e Staphylinidae (Coleoptera) em sistemas de plantio direto e convencional. R Bras Entomol. 53: 432 443.

Martins ICF, Cividanes FJ, Barbosa JC, Lima Junior JA, Campos LD (2016) Population dynamics and spatial distribution of Abaris basistriata Chaudoir, 1873 (Coleoptera: Carabidae). Cien Agrotec. 40: 57-66.

Martins ICF, Cividanes FJ, Ide S, Haddad GQ. (2012) Diversity and habitat preferences of Carabidae and Staphylinidae (Coleoptera) in two agroecosystems. Bragantia. 71: 471480.

Pasini A (1991) Predação de lagartas e pupas de Anticarsia gemmatalis H. (Lep.: Noctuidae) por Calosoma granulatum Perty, 1830 (Col.: Carabidae). In: Reunião Sul-Brasileira de insetos de solo:EMPASC.

Pasini A (1995) Metodologia de criação e biologia de Calosoma granulatum Perty, 1830 (Col.: Carabidae). In: Ciclo de palestras sobre controle biológico de pragas: Campinas Instituto Biológico/SEB, p. 36-37.

Pearce JL, Venier LA. The use of ground beetles (Coleoptera: Carabidae) and spiders (Araneae) as biondicators of sustainable forest management: a review. Ecol Indic. 6: 780-793.

Pegoraro RA, Foerster LA (1988) Abundância e distribuição de larvas e adultos de Calosoma granulatum Perty, 1830 (Coleoptera: Carabidae) dentre cultivares de soja em diferentes épocas de semeadura. An Soc Entomol Bras. 17: 237-248.

Rabinovich JE (1980) Introducción a la ecologia de poblaciones animales. México: Continental, 313p.

Sciarretta A, Trematerra P (2014) Geostatistical Tools for the Study of Insect Spatial Distribution: Practical Implications in the Integrated Management of Orchard and Vineyard Pests. Plant Protect Sci. 50: 97-110.

Taylor LR (1984) Assessing and interpreting the spatial distributions of insect populations. Annu Rev Entomol. 29: 321-357.

Thomas MB, Wratten SD, Sotherton NW (1992) Creation of 'island' habitats in farmland to manipulate populations of beneficial arthropods: Predator densities and species composition. J appl Ecol. 29: 524-531.

Thomas CFG, Holland JM, Brown NJ (2002) The spatial distribution of carabid beetles in agricultural landscapes. In: Holland JM, ed. The agroecology of carabid beetles, Andover: Intercept, p.305-344.

Witmer JE, Hough-Goldstein JA, Pesek JD (2003) Grounddwelling and foliar arthropods in four cropping systems. Environ Entomol. 32: 366-376. 